Hichem Dkhili,

Northern Border University, Saudi Arabia

(iD) ORCID ID, 0000-0001-5773-1494

email: dkili_hichem@hotmail.com

Lasaad Ben Dhiab,

Northern Border University, Saudi Arabia

email:dhiab_@yahoo.fr

Correspondence author: dkili_hichem@hotmail.com

\title{
THE IMPACT OF NATIONAL CULTURE ON ENVIRONMENTAL PERFORMANCE: CASE FOR GSS COUNTRIES
}

Abstract. This paper summarises the arguments and counterarguments within the scientific discussion on national culture and environmental performance. The main paper's goal is to examine the national culture determinants and their impacts on environmental performance. The relevance of this scientific problem's decision is that environmental performance is a relevant objective in the Gulf Council countries (GCC). The investigation of the topic on GCC's national culture in the paper was carried out in a logical sequence. The methodological tool of this research was applied to measure the impact of national culture on environmental performance. For gaining the paper's goal, the study involved the empirical approach justified by using a structural model. The empirical analysis results showed a positive effect of national culture on environmental performance. The findings suggest that Power distance, Individualism, Masculinity, Uncertainty avoidance, Long term orientation moderated the relationship between national culture and environmental performance. The results implied that Power distance, Individualism, Masculinity, Uncertainty Avoidance, and long-term orientation in the GCC's companies had a positive and significant relation with environmental performance. This research could help the GCC companies promote long-term orientation and environmental performance for good development and economic growth. Besides, the author suggested maintaining the environmental performance and limit the average financial performance.

Keywords: national culture, environmental performance, GCC countries.

Introduction. National culture is the fundamental identity of peoples. Despite the various political, economic, and social developments of States, national culture remains an essential factor and an integral part of peoples' living reality. Attention to the cross-cutting themes of environment and sustainable development has also arisen in keeping with new policies and stimulating trends to examine the determinants that interact with environmental performance (Böhringer and Jochem,2007). The increased depletion of core resources and the internationalisation of environmental performance from toxic gas emissions combined with an increase in the economic growth index and a rise in industrialisation and urbanisation.

Saudi Arabia's national identity consists of five components: religion, language, origin, geography and culture. In theory, environmental performance is a composite index that tracks various social, economic, environmental and institutional indicators that characterise environmental sustainability. It also affects the national and global level of State economics. It was launched in 1999 by Professor Daniel Esty, Director of the Yale Center for Environmental Law and Policy, in collaboration with the CIESIN Center and Supervisor of the World Summit for the Global Future of the World Economic Forum.

Cite as: Dkhili, H., \& Dhiab, L. B. (2021). The Impact of National Culture on Environmental Performance: Case for GSS Countries. Marketing and Management of Innovations, 1, 304-311.

304 http://doi.org/10.21272/mmi.2021.1-23 
In 1980, Hofstede and Minkov (2010) revolutionised the world through their comparative research, classifying culture according to 6 testicles. Initially, the model consisted of five variables: Long-term direction, the distance of power, fear of uncertainty, masculinity/femininity, and individuality versus collectivism. Geert Hofstede and Minkov (2010) added the sixth variant called immersion. In this context, our contribution attempts to answer the question of the implications of national culture for the GCC States' environmental performance. We will rely on an experimental model for many indicators. In this context, we ask the following question: What are the impacts of national cultural determinants on environmental performance?

Literature Review. The Johannesburg Summit (2002) was an excellent event for promoting sustainable development. Sustainable development is based on three general principles: equity, precaution and participation. Similarly, sustainable development is reflected in three main lines that allow for performance assessment fewer than three axes: the environmental, social and economic. Societal performance has been the subject of many empirical investigations in the academic world, especially in the Anglo-Saxon context. For example, we witness Margolis Walsh studies (2001). At the same time, there is little empirical research focused on studying the concept of community performance in the GCC. The concept of corporate social performance is central in business research that has evolved in recent years as it seeks to define the different relationships between the company and its environment.

Carroll (1999) and Wartick and Cochran (1985) confirmed the company's ability to express its social responsibility. Through this observation, the evolution of CSR's concept emerges as a new concept that stems from societal acceptance (CSR). In this context, Carroll (1999) defined this idea as having the ability to respond to social pressures. The first theoretical approach suggests that the company is more socially strong. It is more economically and financially efficient. Instead, the company will be more economically and socially successful. This research is the first of its kind, through this scientific contribution to analyse the relationship between the culture of corporate social responsibility and the leadership's performance of social responsibility towards financial performance, with emphasis on the role of mediating organisational culture and transformative leadership.

Hofstede and Minkov (2010) classified the culture according to 6 characteristics. Initially, the model consisted of five variables: long-term orientation, power distance, fear of uncertainty, masculinity/femininity, and individualism versus collectivism. In 2010, Hofstede and Minkov added the sixth variable called indulgence. The research of Al-Tuwaijri et al. (2004) concluded that «good» environmental performance is strongly linked to «environmental» specific pollution measures, and occurrences are disclosed.

Several scientific articles have resumed studies focusing on analysing determinants of the national culture against environmental performance in many countries. Cho et al. (2010) investigated the relationship between corporate disclosure and performance. Branzei et al. (2001) examined the influence of national culture upon leader's interpretations of corporate environmentalism. These authors tried to investigate the influence of national culture, environmental values and socioeconomic contexts upon firm-level greening in both countries. Lenssen et al. (2007) studied the effect of differences in national cultures on companies' social and environmental performance around the world.

Lenssen et al. (2007) proved that companies based in countries characterised by higher power distance levels, individualism, masculinity, and uncertainty avoidance exhibit lower levels of social and environmental performance. Husted (2005) tested the significance of culture in examining the relationship between income and the environment. Furthermore, find that there are significant multidimensional interrelationships among the cultural and environmental sustainability measures. Peng and Lin (2009) interested in the relationship between macro-environmental variables and environmental performance. The purpose of these authors was to construct a model focused on cultural values, population growth, economic development, and environmental performance by incorporating education's 
mediating role. This study showed that national culture, economic development, and population growth would significantly influence environmental performance directly.

Morosini et al. (1998) studied the national cultural distance enhances cross-border acquisition performance by providing access to the targets and/or the acquirer's diverse set of routines and repertoires embedded in national culture. Park et al. (2007) examined the Environmental Kuznets Curve (EKC) phenomenon by studying the EKC notion's applicability when cultural variables are included in the model. Vachon et al. (2010) examined these two trends' conjuncture by assessing the linkage between national culture and corporate sustainable development practices in 55 countries. The results of Vachon et al. (2010) supported the results of Husted's national culture dimensions.

The results of Parboteeah et al. (2012) and Distaso (2007) proved that performance orientation and assertiveness have the desired negative relationship with our dependent variable. Nevertheless, collectivism, future orientation, and human orientation have the desired positive relationship.

Following it, CSR leadership condemns the ethical approach, being a moral example, treating people fairly, and actively managing morality (Alt and Spitzeck, 2016). Besides, it is rumoured that there is a link between leadership and management, which is the key to success. Therefore, CSR is the practical step developed through a set of corporate meanings, beliefs and values, and therefore forms the company's culture. It has also defined as shared behaviours, attitudes and perceptions. A CSR culture has defined as a powerful force that gives meaning to individuals' lives, reduces uncertainty, and creates stability, but the organisation's success or failure has also defined it. These reasons are an incentive to take an interest in a culture of social responsibility within Saudi companies. Besides, this research would provide new ways in the pilot study that can reveal the results of the study of the relationship between the culture of corporate social responsibility and the leadership's performance of social responsibility towards financial performance. This experimental and exploratory study is dealt with based on the role of organisational culture and transformative leadership.

Sprinkle and Maines (2010) interested the subject that Organisations are increasingly concerned about how their actions affect the environment and social welfare. Reverte et al. (2016) focused on the impact of corporate social responsibility practices on a measure of organisational performance encompassing both financial and non-financial indicators and studying the potential mediating role of innovation in the corporate social responsibility-performance relationship.

Wang and Abareshi (2015) proposed a conceptual framework of innovation capability, operation capability and logistics performance in the transport firms. Based on the resource-based view, capability plays a vital role in a firm generating competitive advantages. Hur and Kim (2017) explored CSR culture dynamics and the link to subcultures and suggest that this is a necessary, yet complex, aspect of contemporary CSR analysis and research.

Carrión-Flores and Innes (2010) interested the environmental innovation and toxic air pollution. The results of the study proved that environmental innovation is an essential driver of reducing toxic emissions.

An analysis of the data from (Chikalipah 2017) suggested that a strong institutional climate has a significant impact on microfinance institutions' overall performance.

Stakeholder theory gradually established itself as a framework to further define the group concerning its social responsibilities. The company is in the midst of a range of relationships with partners who are not only shareholders but also actors interested or affected in the company's activities and decisions. Stakeholder theory is not devoid of a normative and ethical vision but seeks to integrate economic objectives: it confirms that cooperation agreements establish trust between the company and stakeholders and provide a competitive advantage.

The findings from this research highlighted the importance of cultivating and promoting CSR culture and leadership to influence financial performance positively. This contribution's methodological tools 
examine empirically the effect of CSR culture and CSR Leadership performance towards financial performance and the role of the organisational culture and transformational leadership as mediating's variables. This study's hypotheses are as follow:

$\mathrm{H} 1$ : The determinants of culture have a positive impact on environmental performance.

$\mathrm{H}$ 2: The power distance has a positive impact on environmental performance.

$\mathrm{H3}$ : Individualism has a positive impact on environmental performance.

H4: Masculinity has a positive impact on environmental performance.

$\mathrm{H} 5$ : Uncertainty avoidance has a positive impact on environmental performance.

H6: The long term orientation has a positive impact on environmental performance.

$\mathrm{H} 7$ : Indulgence has a positive impact on environmental performance.

Methodology and research methods. Our model combines culture and environment performance with institutional variables (Population Growth and Economic Growth) this model can be presented as follow:

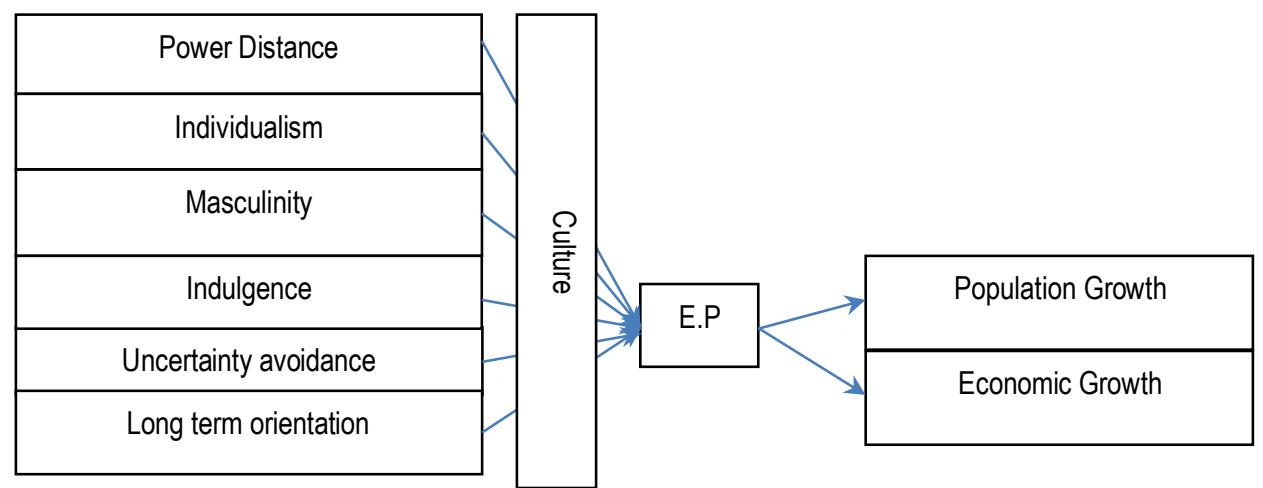

Figure1. Research Model

Sources: developed by the authors.

These variables could be operationalised with various items formulated as questions. They were collected on Likert scales of 5 points (ranging from «disagree» to «strongly agree»). Two successive optimisations provided the quality of the measurement scales. First, a factor analysis of type PCA (Principal Component Analysis) was performed to verify the scales' validity and thus confirm the sought after factors. The second phase of optimisation scales was a confirmatory structural analysis performed with the AMOS software. Structural equation modelling was used to test the research proposal. Finally, it was detailed the results of the fit of the structural model with the empirical data, based on the indices of modifications suggested by the AMOS software. In this context, three steps were necessary to adjust the measurement models confirmatory factor analysis, reliability test and estimation of the measurements' validity. During the exploratory phase, the reliability of the measurement scales was tested using the Cronbach Alpha Index. The sample of this research was composed of GCC countries. Subsequently, the data were collected through a pre-established electronic questionnaire and sent to different GCC countries.

Results. This section of the study investigates the nature of the relationships between national cultures and environmental performance. The estimation was performed iteratively using the maximum likelihood method, which is advocated by default as the best methods tested. The level of fit of the model 
was estimated by the chi-square statistic $(x 2)$, which is considered good when the p-value associated with $(x 2)$ is more significant than $5 \%$.

The results show a (X2) equal to $(0,065)$ with a p-value equal $(0,005)$, the GFI (Goodness of Fit), the RMR (Root Mean Square Residual), as well as other comparators such as AIC (Akaike Information Criterion).

Table 1. Results of the exploratory factor analysis

\begin{tabular}{lccc}
\hline $\begin{array}{c}\text { Indices of the goodness of } \\
\text { fit }\end{array}$ & KMO Indices & Cronbach Alpha & Significance of Bartlett \\
\hline Power distance & 0,770 & 0,887 & 0,000 \\
Individualism & 0,597 & 0,697 & 0,000 \\
Masculinity & 0,557 & 0,658 & 0,000 \\
Uncertainty avoidance & 0,613 & 0,749 & 0,000 \\
Long term orientation & 0,684 & 0.885 & 0,000 \\
\hline
\end{tabular}

Sources: developed by the authors.

After testing the model using structural equations, it appears that the conditions tested model fit the data are generally observed: The associated p-value equals $(0.045)$, which is greater than $(0.005)$. GFI coefficient is higher than the norm (0.968), the GFI $=0.978$. This value reflects a good «it» between model and data. At this level, the two research hypotheses and the overall hypothesis can be broadly adopted. Besides, the RMR index (in terms of residual variance, that is to say, unexplained variance) is very low, it is equal to 0.045 . Side indices to judge the model's quality of fit, such as the CFI, are equal to 0.983 . The RMSEA is equal to 0.043 ; AIC is equal to $(147,025)$ strictly less than the saturated model $(127,128)$. The values of $X 2(48.257)$ and CFI $(0.983)$ estimated by AMOS indicate that the overall fit of the model is very high. Therefore, we can conclude that the fit of the proposed model is acceptable according to the results, indices assessment used.

Table 2. Test results of the structural model

\begin{tabular}{|c|c|c|}
\hline Goodness of fit index & Acceptability threshold & Value found \\
\hline$x^{2}(p$-value associated $)$ & & 48.257 \\
\hline$x^{2} / \mathrm{ddl}$ & p must be> 0.05 do not reject the model & $P=0,045$ \\
\hline GFI & $>0,9$ & 0,968 \\
\hline TLI & $>0,9$ & 0,957 \\
\hline CFI & $>0,9$ & 0,983 \\
\hline RMR & $<0,08$ & 0,035 \\
\hline RMSEA & $<0,08$ and possibly $<0,06$ & 0,043 \\
\hline CAIC model tested & CAIC model tested must be lower than the & 147,025 \\
\hline CAIC saturated model & saturated model / independence ${ }^{2}$ & 127,128 \\
\hline
\end{tabular}

Sources: developed by the authors.

The structural model was converting to factor scores. With the utilisation of the method of Anderson Rubin. This method provided by the SPSS statistical software to calculate factor scores for each measurement scale based on items selected. The structural model is shown in Table 3. Thus, the following table with the structural model's test results shows a perfect fit judged by indices.

Table 3 shows a positive relationship between quality indicators: National culture (Power distance, Individualism, Masculinity, Uncertainty avoidance, Long term orientation) and environmental performance. The output states of AMOS show that all the coefficients' regression is significant; the 
student's test (R.C.) is greater than 1.96 for all the model variables. This confirms that the overall model is acceptable.

Table 3.Significance of the model parameters

\begin{tabular}{lcccc}
\hline \multicolumn{1}{c}{ Regression coefficient } & Estimate & (S.E.) & (R.C.) & P \\
\hline Power distance <--- Environmental performance & 0,986 & 4,766 & 9,723 & $* * *$ \\
Individualism <--- Environmental performance & 2,076 & 2,313 & 9,723 & $* * *$ \\
Masculinity <--- Environmental performance & 2,183 &, 813 & 8,226 & $* * *$ \\
Uncertainty avoidance <--- Environmental performance & 1,525 &, 840 & 9,036 & $* * *$ \\
Long term orientation <--- Environmental performance & 2,335 & 1,266 & 11,149 & $* * *$ \\
\hline
\end{tabular}

Sources: developed by the authors.

Through the analysis results, it is clear that there is complete agreement in the respondents' opinions on the importance of National culture (Power distance, Individualism, Masculinity, Uncertainty avoidance, Long term orientation). The results of the structural and principal component analyses indicate a positive relationship between Power distance, Individualism, Masculinity, Uncertainty avoidance, Long term orientation and environmental performance. In a broader sense, these results confirm that National culture is an essential factor in interpreting environmental performance. This is clear from the finding of this study. The results of the study can be summarised as follows:

There is complete agreement in respondents' views about the appropriate Power distance, Individualism, Masculinity, Uncertainty avoidance and Long term orientation for GCC companies in improving a higher environmental performance index. Also, long term orientation and Power distance are positively linked with the environmental performance index in GCC countries with a higher population rate.

This study confirms the positive linear relationship between the variables in the context of GCC companies in particular. These results are consistent with the findings of earlier studies such as Vachon et al. (2010), Parboteeah et al. (2012), Lenssen et al. (2007) and Husted (2005).

Overall, the study indicates that the determinants of culture have a positive impact on environmental performance. So, power distance, individualism, masculinity, uncertainty avoidance, long-term orientation, and indulgence positively impact environmental performance.

Conclusion. This study attempts to shed light on the link between Power distance, Individualism, Masculinity, Uncertainty avoidance, Long term orientation and environmental performance for GCC companies. The study identified and analysed the determinants of National culture and their implications for environmental performance. The data were collected using a questionnaire and processed using exploratory and confirmatory analysis using structural equations. The survey covered a sample of 300 companies of GCC companies.

The results show a strong relationship between Power distance, Individualism, Masculinity, Uncertainty avoidance, Long term orientation and environmental performance. In particular, the results showed that high environmental performance is reflected by National culture.

Funding: This research was funded by the deanship of Scientific Research, Northern Border University and The APC was funded by grant $\mathrm{N} 0(435 / 000)$.

Author Contributions: conceptualisation, D. H.; methodology, D. H.; software, D. H.; validation, D. H., and B.D.A.; formal analysis, D. H., and B.D.A.; investigation, D. H.; resources, D. H.; data curation, D. H.; writing-original draft preparation, D. H.; review and editing; D. H., and B. D. A.; visualisation, D. H., and B.D. A.; supervision, B.D.A.; project administration, B. D. A.; funding acquisition, D. H. 


\section{References}

Alt, E., \& Spitzeck, H. (2016). Improving environmental performance through unit-level organisational citizenship behaviors for the environment: A capability perspective. Journal of environmental management, 182, 48-58. [Google Scholar] [CrossRef]

Al-Tuwaijir, S. A., Christensen, T. E., \& Hughes, K. (2004). The relations among environmental disclosure, environmental performance, and economic performance: a simultaneous equations approach. Accounting, Organisations and Society, 29(5-6), 447-471. [Google Scholar] [CrossRef]

Böhringer, C., \& Jochem, P. E. (2007). Measuring the immeasurable-A survey of sustainability indices. Ecological Economics, 63(1), 1-8. [Google Scholar] [CrossRef]

Branzei, O., Vertinsky, I., Takahashi, T., \& Zhang, W. (2001). Corporate environmentalism across cultures: A comparative field study of Chinese and Japanese executives. International Journal of Cross-Cultural Management, 1(3), 287-312. [Google Scholar] [CrossRef]

Carrión-Flores, C. E., \& Innes, R. (2010). Environmental innovation and environmental performance. Journal of Environmental Economics and Management, 59(1), 27-42. [Google Scholar] [CrossRef]

Carroll, A. B. (1999). Corporate social responsibility: Evolution of a definitional construct. Business \& Society, 38(3), 268-295. [Google Scholar] [CrossRef]

Chikalipah, S. (2017). Institutional environment and microfinance performance in Sub-Saharan Africa. African Development Review, 29(1), 16-27. [Google Scholar] [CrossRef]

Cho, C. H., Roberts, R. W., \& Patten, D. M. (2010). The language of US corporate environmental disclosure. Accounting, Organisations and Society, 35(4), 431-443. [Google Scholar] [CrossRef]

Distaso, A. (2007). Well-being and/or quality of life in EU countries through a multidimensional index of sustainability. Ecological Economics, 64(1), 163-180. [Google Scholar] [CrossRef]

Hofstede, G., \& Minkov, M. (2010). Long-versus short-term orientation: new perspectives. Asia Pacific business review, 16(4), 493-504. [Google Scholar] [CrossRef]

Hur, W. M., \& Kim, Y. (2017). How does culture improve consumer engagement in CSR initiatives? The mediating role of motivational attributions. Corporate Social Responsibility and Environmental Management, 24(6), 620-633. [Google Scholar] [CrossRef

Husted, B. W. (2005). Culture and ecology: A cross-national study of the determinants of environmental sustainability. MIR: Management International Review, 349-371. [Google Scholar]

Lenssen, G., Perrini, F., Tencati, A., Lacy, P., Ringov, D., \& Zollo, M. (2007). The impact of national culture on corporate social performance. Corporate Governance: The international journal of business in society. [Google Scholar] [CrossRef]

Morosini, P., Shane, S., \& Singh, H. (1998). National cultural distance and cross-border acquisition performance. Journal of international business studies, 29(1), 137-158. [Google Scholar] [CrossRef]

Parboteeah, K. P., Addae, H. M., \& Cullen, J. B. (2012). Propensity to support sustainability initiatives: A cross-national model. Journal of business ethics, 105(3), 403-413.. [CrossRef]

Park, H., Russell, C., \& Lee, J. (2007). National culture and environmental sustainability: A cross-national analysis. Journal of Economics and Finance, 31(1), 104-121. [Google Scholar] [CrossRef]

Peng, Y. S., \& Lin, S. S. (2009). National Culture, Economic Development, Population Growth and Environmental Performance: The Mediating Role of Education. Journal of business ethics, 90(2), 203-219. [Google Scholar] [CrossRef]

Reverte, C., Gomez-Melero, E., \& Cegarra-Navarro, J. G. (2016). The influence of corporate social responsibility practices on organisational performance: evidence from Eco-Responsible Spanish firms. Journal of Cleaner Production, 112, 2870-2884. [Google Scholar] [CrossRef]

Sprinkle, G. B., \& Maines, L. A. (2010). The benefits and costs of corporate social responsibility. Business Horizons, 53(5), 445-453 [Google Scholar] [CrossRef]

Vachon, D., Prairie, Y. T., \& Cole, J. J. (2010). The relationship between near-surface turbulence and gas transfer velocity in freshwater systems and its implications for floating chamber measurements of gas exchange. Limnology and Oceanography, 55(4), 1723-1732. [Google Scholar] [CrossRef]

Wang, M., Jie, F., \& Abareshi, A. (2015). Evaluating logistics capability for mitigation of supply chain uncertainty and risk in the Australian courier firms. Asia Pacific Journal of Marketing and Logistics. [Google Scholar] [CrossRef]

Wartick, S. L., \& Cochran, P. L. (1985). The evolution of the corporate social performance model. Academy of management review, 10(4), 758-769. [Google Scholar] [CrossRef]

Хічем Дхілі, Північний прикордонний університет в Арарі, Саудівська Аравія

Лассаад Бен Дхіаб, Північний прикордонний університет в Арарі, Саудівська Аравія.

Вплив національної культури на рівень екологічної ефективності: кейс для країн Перської затоки

У статті узагальнено аргументи та контраргументи в рамках наукової дискусії щодо взаємозв'язку між національною культурою та рівнем екологічної ефективності країн. Систематизація літературних джерел та підходів до вирішення проблеми екологічного розвитку країн засвідчила, що її національна культура розглядається науковою спільнотою як одна 
з ключових детермінант підвищення його рівня. Основною метою роботи є дослідження впливу детермінант національної культури на рівень екологічного розвитку країн. У роботі зазначено, що країнами Перської затоки приділяється особлива увага управлінню навколишнім природним середовищем та покращенню рівня його розвитку. Дослідження висунутої в роботі гіпотези про статистично значимий вплив детермінант національної культури на показники рівня екологічної розвитку країн в статті здійснено в наступній логічній послідовності: дослідження основних детермінант національної культури; побудова структурної моделі дослідження лінійного зв'язку між явними і латентними змінними. Об'єктом дослідження $€$ компанії країн Перської затоки. За результатами емпіричного аналізу встановлено позитивний вплив національної культури на екологічну ефективність. Отримані результати засвідчили, що досліджувані змінні (віддалене управління, індивідуалізм, уникнення невизначеності, довгострокова орієнтація) $€$ модераторами взаємозв'язку між національною культурою та рівнем екологічного розвитку країни. При цьому результати дослідження дають підстави стверджувати, що культура компаній у державах Перської затоки щодо віддаленого управління, індивідуалізму, маскулінності, уникнення невизначеності та довгострокової орієнтації мала позитивний вплив на екологічні показники Результати проведеного дослідження можуть бути корисними для компаній держав Перської затоки та сприяють довгостроковій орієнтації на досягнення високого рівня екологічного розвитку країни з метою забезпечення ії̈ економічного зростання.

Ключові слова: національна культура, екологічна ефективність, держави Перської затоки. 